\title{
Oncocytic Breast Carcinoma
}

National Cancer Institute

\section{Source}

National Cancer Institute. Oncocytic Breast Carcinoma. NCI Thesaurus. Code C40366.

A rare breast adenocarcinoma characterized by the presence of neoplastic oncocytic cells. The oncocytic cells comprise more than 70 percent of the malignant cellular population. 